\title{
Biomechanics Analysis of Elementary School Students' Fundamental Movement Skill (FMS)
}

\author{
Muchamad Arif Al Ardha ${ }^{1, *}$, Chung Bing Yang ${ }^{2,}$ Nurhasan $^{3,}$ Dwi Cahyo Kartiko, \\ Bambang Ferianto Tjahyo Kuntjoro ${ }^{5,}$ Kolektus Oky Ristanto ${ }^{6,}$, Andhega Wijaya ${ }^{7}$
} Kartika Rinakit Adhe ${ }^{8,}$ Kukuh Pambuka Putra ${ }^{9,}$ Fajar Awang Irawan ${ }^{10,}$ Rizky Patria Nevangga ${ }^{11,}$ Niken Sasadhara Sasmita ${ }^{12,}$ Ainun Zulfikar Rizki ${ }^{13}$

\author{
1,3,4,5,6,7 Physical Education Department, Universitas Negeri Surabaya, Indonesia \\ ${ }^{2}$ Physical Education and Kinesiology Department, National Dong Hwa University, Taiwan \\ ${ }^{8}$ Early Childhood Education Department, Universitas Negeri Surabaya, Indonesia \\ ${ }^{9}$ Faculty of Medicine and Health Science, Universitas Kristen Satya Wacana, Indonesia \\ ${ }^{10}$ Sports Science Department, Universitas Negeri Semarang, Indonesia \\ ${ }^{11,12}$ Sport Coaching Education Department, Universitas Negeri Surabaya, Indonesia \\ ${ }^{13}$ Master Program in Sport Education, Universitas Negeri Surabaya, Indonesia \\ *Corresponding author. Email: muchamadalardha@unesa.ac.id
}

\begin{abstract}
Fundamental movements are part of teaching objectives in the physical education curriculum for elementary schools students. This study aimed to analyze the elementary school students' basic movement skills (FMS) using the kinematic approach. The fundamental movements in this research were correlated with lower body parts, i.e., one leg standing position with closed eyes (non-locomotor), hopping (locomotor), running (locomotor), and kicking (manipulative). This was comparative research that was conducted in a quantitative approach. The random sampling method selected 126 elementary students ( 75 male and 51 female) aged $8.96 \pm 1.50$ years old. The kinematic data were collected by using kinematic video analysis in Kinovea 0.9.4 computer software. The independent variables were one leg standing position in second, distance per step (DPS) in centimeter, speed per step (SPS) in meter per second, step height (SH) in centimeter, kicking speed (KS) in meter per second, and estimated maximum distance (MD) in centimeter. All variables were measured both left and right foot. The data were analyzed using descriptive analysis and the Mann-Whitney U test to find the significant difference between gender. The results showed only two independent variables were significantly different. In hopping, there was left foot height $(\alpha=0.044)$ and left foot speed $(\alpha=0.043)$. In conclusion, elementary school students aged $8.96 \pm 1.50$ years old have a similar fundamental movement skill.
\end{abstract}

Keywords: Fundamental movements, Non-locomotor, Locomotor, Manipulative.

\section{INTRODUCTION}

Physical education uses physical activity to improve physical fitness and motor skills [1]. The physical education curriculum in elementary schools explains that physical education is an educational process that is systematically planned and utilizes physical activity aimed at improving individual quality neuromuscular, cognitive, social, and emotional [2]. Furthermore, it also plays a vital role in developing personality values through sports [3]. Physical education has three basic principles, i.e., (1) Fun physical education program is needed so that learning becomes effective, (2) The curriculum is necessary to provide skills development for students, (3) The curriculum needs to help create good health, physical activity, and physical fitness [4]. Elementary school students tend to imitate someone as a figure in their period of playing and learning [5]. Furthermore, it is essential to be implemented in the teaching strategies [6].

Fundamental movements are part of teaching objectives in the physical education curriculum for elementary schools students. Basic movements consist of locomotor, non-locomotor, and manipulative motion [7]. 
Fundamental movements are essential before the students start the training in a specific sport skill [8]. The extraordinary ability of fundamental movements will allow the student to participate better in Sport or any physical activity [9]. Basic movements in certain sports, such as taekwondo is an effective way to improve posture [10]. Every child can reach the stage of gross motor development, especially when getting the proper stimulation [11]. However, in some special need conditions, the result could be deficient [12].

Basic locomotor motion is the behavior of moving the body from one place to another [13]. The locomotor motions are running, jumping, leaping, hopping, and others [9]. Locomotor motion is the basis for developing coordination of movements involving gross muscles, muscle growth, endurance, and stamina [14]. It could be trained together in rhythmic movement [15]. Nonlocomotor motion is the ability to be balanced and stable [9]. The movement is carried out in place, i.e., static balance, static bend, static push, static pull, and others [16]. Manipulative skills are related to controlling the objects [17]. Manipulative motions are kicking, throwing, and hitting [9]. It can be improved by using specific sports skills and also traditional games [18].

One leg standing position with closed eyes is a test to determine a person's balance duration. According to Morioka et al. (2012), The balance ability begins to decline in the late 20s. Decreased plantar sensation appears to be associated with a reduced duration of standing on one leg. Furthermore, age and two-point plantar discrimination had a significant positive correlation, and two-point discrimination distance and time standing on one leg had a significant negative correlation.

Hopping is defined as jumping forward on one leg. According to Fukashiro et al. (1995), the Achilles tendon's peak mechanical strength and work in the calf muscles were $2233 \mathrm{~N}$ and $34 \mathrm{~J}$ in the squat jump, $1895 \mathrm{~N}$ and $27 \mathrm{~J}$ in the counter jump, and $3786 \mathrm{~N}$ and $51 \mathrm{~J}$ during hopping. Hopping is a gross motor skill that requires fullbody vertical rigidity and control of horizontal movements, especially when trying to change jumping frequency [21]. Based on research data by Akay et al. (2006), hopping movements of the hind legs are not always associated with synchronous movements of the forelegs.

Running is a different movement from walking, especially in the absence of periods of double support. In the running, there are 2 phases, namely the stance and swing phase. According to Hamilton et al. (2008), the muscles involved in the running perspective are gastrocnemius soleus, quadriceps femoris, gluteus maximus, and hamstring at the ankles, knees hips, with the support of the toe muscles, namely $\mathrm{m}$. flexor hallucis longus, flexor digitorum longus and intrinsic flexor. The short toes contract in response to ground pressure on the toes. In the propulsive phase, the contractions of these muscles are intensified. The toe flexor muscle contractions were more significant during the entire support phase when not wearing footwear Hamilton et al. (2008). In the pelvis, there are movements of flexion, lateral rotation (due to pelvic rotation), adduction (occurring early in the phase), and abduction at the end of the stage. These movements arise mainly when long strides are performed. It can also be caused by pelvic rotation Hamilton et al. (2008). The muscles involved in the swing phase are the tibialis anterior, extensor dithorium, longus, extensor hallux longus, reflex action and momentum, hamstring, iliopsoas rectus femoris.

Players require passing and kicking skills to kick a moving ball, sent at a constant speed, towards one of four randomly determined targets [24]. The action in kicking occurs in the sagittal plane about the transverse axis and involves the hip, knee, and ankle joints. The hip bones involved are the femur and the pelvic girdle that form the ball and joint cavity. The knee bones involved are the femur and tibia, which include the hinge joint. The ankle bones involved are the tibia and calcaneus, which form the modified joint. Kicking consists of two phases, the preparation phase and the kicking phase [25].

Sports Biomechanics is the science that applies the laws of mechanics to living structures, especially the body's locomotor system. Biomechanics analysis provides quantitative and qualitative data to explain the human body movement mechanism [26]. The aims or sports biomechanics are (1) provide an evaluation of sports movements (techniques) so that they are carried out correctly, effectively, and efficiently [27]; (2) assessing aspects that could potentially cause injury; (3) assisting the recovery process for athletes who are injured; and (4) discuss externally generated forces that have the potential to affect athlete performance, such as gravity and frictional forces. The analysis of an athlete's performance can be implemented during a training session [28] or while participating in a championship [29].

Children have many unstructured physical activities and movements [30]. Sports biomechanics could analyze and improve the children's fundamental movement skills by using a detailed diagnostic and feedback on the movement skills which they performed. This study aimed to investigate the elementary school students' basic movement skills by using the kinematic approach. The basic movements in this research were correlated with lower body parts, i.e., one leg standing position with closed eyes (non-locomotor), hopping (locomotor), running (locomotor), and kicking (manipulative). There are two research questions in this study: 
1. Are there any significant differences between male and female fundamental movement skills?

2. Are there any significant differences between right and left foot fundamental movement skills?

\section{METHODS}

\subsection{Design and Sample}

This study was conducted in a quantitative approach. The research design was approved by Universitas Negeri Surabaya Ethics Committee. There were 126 elementary students ( 75 male and 51 female) aged $8.96 \pm 1.50$ years old who participated in this study and were chosen as research samples using a random sampling method.

Table 1. Research samples descriptive analysis

\begin{tabular}{|c|c|c|c|}
\hline \multirow{2}{*}{ Gender } & \multicolumn{3}{|c|}{ Mean \pm SD } \\
\cline { 2 - 4 } & Age & Weight $(\mathrm{kg})$ & Height $(\mathrm{cm})$ \\
\hline Male $(\mathrm{n}=75)$ & $9.01 \pm 1.05$ & $29.13 \pm 7.63$ & $128.58 \pm 5.76$ \\
\hline Female $(\mathrm{n}=51)$ & $8.88 \pm 1.52$ & $30.00 \pm 6.11$ & $127.45 \pm 4.48$ \\
\hline Total $(\mathrm{n}=126)$ & $8.96 \pm 1.50$ & $29.48 \pm 7.04$ & $128.12 \pm 5.29$ \\
\hline
\end{tabular}

\subsection{Data Collection}

The kinematic data were collected by using kinematic video analysis in Kinovea 0.9.4 computer software. The fundamental movement data were measured by kinematic analysis. The non-locomotor movement was one leg standing position with closed eyes in both left and right foot (figure 1). The measurement was using a timer (second). It started when the student was in the one leg standing position and ended when the student changed the pedestal position or dropped the other food due to losing balance.

The locomotor movements were hopping and running. The analysis was based on each step of those movements, both left and right foot (figure 2 and 3 ). The variables were distance per step (DPS) and speed per step (SPS). In addition, there was step height ( $\mathrm{SH}$ ) in hopping was also measured. The manipulative movements were kicking the ball both using left and right foot (figure 4). The analysis focused on kicking speed (KS) and maximum distance (MD), which were estimated using the projectile motion formula. The formula was Maximum Distance $=\left(\mathrm{Vo}^{2} \times \sin 2 \theta\right) / \mathrm{g}$.

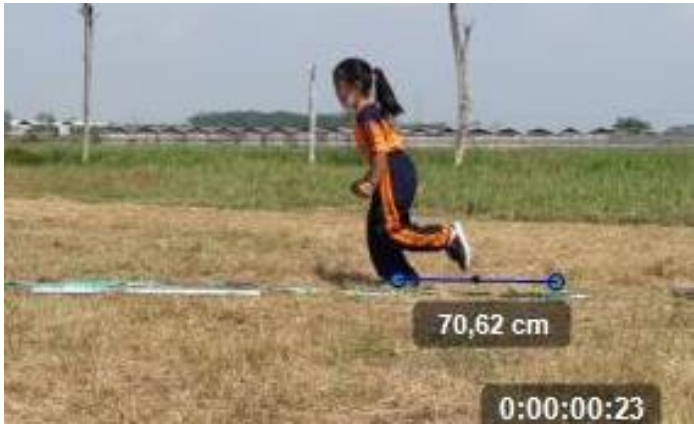

Figure 1 One leg standing position with closed eyes

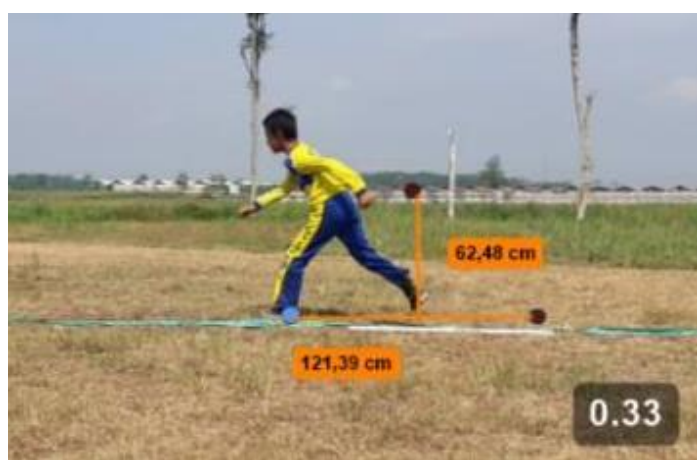

Figure 2. Hopping

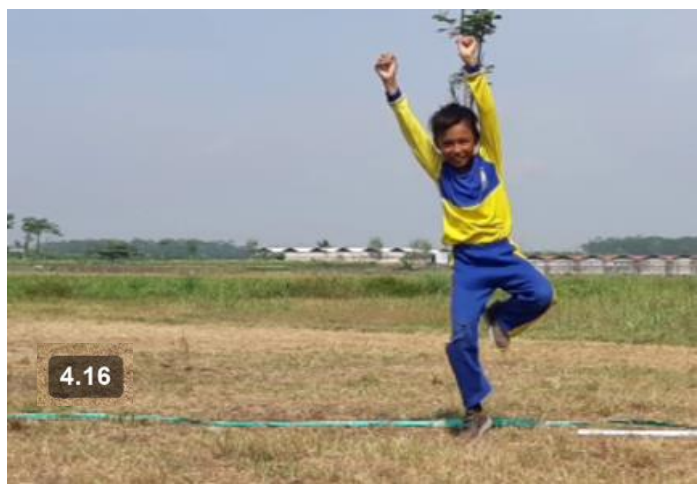

Figure 3. Running

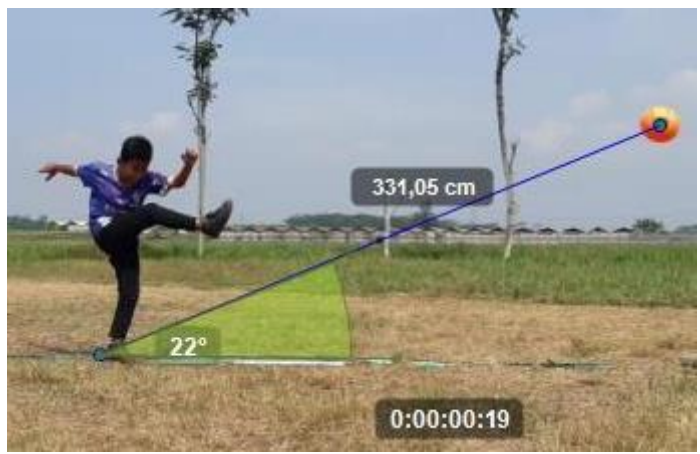

Figure 4. Kicking

\subsection{Data Analysis}

The data were analyzed by using descriptive analysis in SPSS statistical software. Kolmogorov Smirnov normality test was applied to decide the further research. 
Data measurements were presented in mean and standard deviation $(\overline{\mathrm{x}} \pm \mathrm{SD})$. The significance level was set at $\alpha<0,05$, and all tests were two-tailed.

\section{RESULTS AND DISCUSSIONS}

Based on the normality test by Kolmogorov Smirnov, the data were not in the normal distribution. Furthermore, the Mann-Whitney $U$ test was performed to find the significant difference between gender (Table 2). The results showed hopping height $(\alpha=0.044)$ and hopping speed $(\alpha=0.043)$ in the left foot were significantly different.

Table 2. Mann Whitney U test

\begin{tabular}{|c|c|c|c|c|}
\hline \multirow{2}{*}{ FMS } & \multicolumn{3}{|c|}{ Mean \pm SD } & \multirow[b]{2}{*}{ Sig. } \\
\hline & Male $(n=75)$ & $\begin{array}{l}\text { Female } \\
(n=51)\end{array}$ & $\begin{array}{c}\text { Total } \\
(\mathrm{n}=126)\end{array}$ & \\
\hline \multicolumn{5}{|c|}{ Non-locomotor movement (One Leg Standing Position) } \\
\hline Right foot balance & $3.81 \pm 1.17$ & $4.07 \pm 1.09$ & $3.92 \pm 1.14$ & 0.229 \\
\hline Left foot balance & $3.97 \pm 1.25$ & $3.91 \pm 1.08$ & $3.94 \pm 1.18$ & 0.676 \\
\hline \multicolumn{5}{|c|}{ Locomotor movement (Hopping) } \\
\hline Right foot distance & $\begin{array}{c}114.53 \pm \\
22.88\end{array}$ & $\begin{array}{l}117.26 \pm \\
20.76\end{array}$ & $\begin{array}{c}115.64 \pm \\
22.01\end{array}$ & 0.386 \\
\hline Right foot height & $51.93 \pm 8.31$ & $51.96 \pm 6.38$ & $51.94 \pm 7.57$ & 0.952 \\
\hline Right foot speed & $3.60 \pm 0.44$ & $3.62 \pm 0.33$ & $3.61 \pm 0.40$ & 0.435 \\
\hline Left foot distance & $\begin{array}{c}117.37 \pm \\
19.92\end{array}$ & $\begin{array}{l}109.97 \pm \\
23.38\end{array}$ & $\begin{array}{l}114.38 \pm \\
21.61\end{array}$ & 0.062 \\
\hline Left foot height & $52.17 \pm 7.59$ & $49.37 \pm 7.04$ & $51.04 \pm 7.47$ & $0.044 *$ \\
\hline Left foot speed & $3.57 \pm 0.36$ & $3.67 \pm 0.41$ & $3.61 \pm 0.38$ & $0.043 *$ \\
\hline \multicolumn{5}{|c|}{ Locomotor movement (Running) } \\
\hline Right foot distance & $\begin{array}{l}79.26 \pm \\
10.33 \\
\end{array}$ & $78.07 \pm 8.91$ & $78.78 \pm 9.76$ & 0.612 \\
\hline Right foot speed & $4.92 \pm 0.73$ & $4.87 \pm 0.54$ & $4.90 \pm 0.66$ & 0.852 \\
\hline Left foot distance & $\begin{array}{l}80.31 \pm \\
11.14 \\
\end{array}$ & $76.56 \pm 8.71$ & $\begin{array}{l}78.79 \pm \\
10.35 \\
\end{array}$ & 0.082 \\
\hline Left foot speed & $4.93 \pm 0.67$ & $4.83 \pm 0.59$ & $4.88 \pm 0.64$ & 0.665 \\
\hline \multicolumn{5}{|c|}{ Manipulative movement (Kicking) } \\
\hline $\begin{array}{l}\text { Right foot kicking } \\
\text { speed }\end{array}$ & $19.68 \pm 4.40$ & $19.14 \pm 3.58$ & $19.46 \pm 4.08$ & 0.756 \\
\hline $\begin{array}{l}\text { Right foot kicking } \\
\text { distance }\end{array}$ & $18.79 \pm 5.45$ & $20.19 \pm 5.34$ & $19.36 \pm 5.42$ & 0.093 \\
\hline $\begin{array}{l}\text { Left foot kicking } \\
\text { speed }\end{array}$ & $19.54 \pm 3.69$ & $19.21 \pm 3.70$ & $19.41 \pm 3.69$ & 0.680 \\
\hline $\begin{array}{l}\text { Left foot kicking } \\
\text { distance }\end{array}$ & $18.76 \pm 6.14$ & $19.85 \pm 4.97$ & $19.20 \pm 5.70$ & 0.432 \\
\hline
\end{tabular}

Notes :

* Significant $<0.05$

Based on the Mann-Whitney U test, there were no significant differences between gender in most of the fundamental movements' skills. In other words, there were no significant differences between male and female students in one leg standing position, running, and kicking. The fundamental movement skill is an essential part of physical activity [31]. Furthermore, the similar important movement skill is reflected in the physical activity performed by both males and females [32]. In the previous study about kicking manipulative skills, there were no significant differences between gender in the pretest [33]. There were also no significant differences in manipulative ability among children [34].

Wilcoxon's two related sample tests were also implemented to analyze the significant difference between left and right foot (table 3 ). There were no significant differences between left and right foot in all of the fundamental movements' skills.

Table 3. Wilcoxon two related sample tests

\begin{tabular}{|c|c|c|}
\hline & Mean \pm SD & Sig. \\
\hline \multicolumn{3}{|c|}{ Non-locomotor movement (One Leg Standing Position) } \\
\hline Right foot balance & $3.92 \pm 1.14$ & \multirow[b]{2}{*}{0.825} \\
\hline Left foot balance & $3.94 \pm 1.18$ & \\
\hline \multicolumn{3}{|c|}{ Locomotor movement (Hopping) } \\
\hline Right foot distance & $115.64 \pm 22.01$ & \multirow[b]{2}{*}{0.534} \\
\hline Left foot distance & $114.38 \pm 21.61$ & \\
\hline Right foot height & $51.94 \pm 7.57$ & \multirow[b]{2}{*}{0.213} \\
\hline Left foot height & $51.04 \pm 7.47$ & \\
\hline Right foot speed & $3.61 \pm 0.40$ & \multirow[b]{2}{*}{0.469} \\
\hline Left foot speed & $3.61 \pm 0.38$ & \\
\hline \multicolumn{3}{|c|}{ Locomotor movement (Running) } \\
\hline Right foot distance & $78.78 \pm 9.76$ & \multirow[b]{2}{*}{0.972} \\
\hline Right foot speed & $78.79 \pm 10.35$ & \\
\hline Left foot distance & $4.90 \pm 0.66$ & \multirow[b]{2}{*}{0.930} \\
\hline Left foot speed & $4.88 \pm 0.64$ & \\
\hline \multicolumn{3}{|c|}{ Manipulative movement (Kicking) } \\
\hline Right foot kicking speed & $19.46 \pm 4.08$ & \multirow[b]{2}{*}{0.941} \\
\hline Left foot kicking speed & $19.41 \pm 3.69$ & \\
\hline Right foot kicking distance & $19.36 \pm 5.42$ & \multirow[b]{2}{*}{0.924} \\
\hline Left foot kicking distance & $19.20 \pm 5.70$ & \\
\hline
\end{tabular}

Notes :

* Significant $<0.05$

The development of fundamental movement skills, both right and left foot are well balanced. It is possibly caused by the appropriate activity, which could stimulate both sides of the foot to move equally. Furthermore, inappropriate support and stimulus of motoric could reduce motor coordination [35]. Training activity could be conducted to enhance the mastery of fundamental movement skills [36]. Parents' roles are essential to support the fundamental movement skill [37]. Children with good basic movement skills could perform better and enjoy participating in physical activity or Sport [34].

\section{CONCLUSION}

There were significant differences between male and female FMS, particularly on the hopping left foot height and speed. However, there were no significant differences between right and left foot FMS. Future research could be conducted in a larger society to inquire about the FMS, particularly in elementary school students. 


\section{ACKNOWLEDGMENTS}

The research was funded by Universitas Negeri Surabaya in Research Competition Scheme 2021.

\section{REFERENCES}

[1] G. Le Masurier and C. B. Corbin, "Top 10 Reasons for Quality Physical Education," J. Phys. Educ. Retreat. Dance., vol. 77, no. 6, 2006, DOI: 10.1080/07303084.2006.10597894.

[2] Depdiknas, Kurikulum 2004 Standar kompetensi mata pelajaran pendidikan jasmani Sekolah Dasar dan Madrasah Ibtidaiyah / Departemen Pendidikan Nasional. Jakarta: Depdiknas, 2004.

[3] H. K. Mikalsen and P. A. Lagestad, "Adolescents' meaning-making experiences in physical education-in the transition from primary to secondary school," Sport. Educ. Soc., vol. 25, no. 7, 2020, DOI: 10.1080/13573322.2019.1662389.

[4] P. Eich, "CrossFit Kids as a Physical-Education Curriculum: A Pedagogical Perspective Phil," Crossfit J., pp. 1-12, 2013.

[5] J. Alfin, “Analisis karakteristik siswa pada tingkat sekolah dasar," pp. 190-205, 2015.

[6] N. Septianti and R. Afiani, "Pentingnya Memahami Karakteristik Siswa Sekolah Dasar di SDN Cikokol 2," As-Sabiqun, vol. 2, no. 1, pp. 7-17, 2020, doi: 10.36088/assabiqun.v2i1.611.

[7] A. Amirzan, "Pengembangan Model Pembelajaran Gerak Dasar Lokomotor Pada Siswa SD Kelas V," J. Phys. Educ. Heal. Recreat., vol. 2, no. 1, 2017, doi: 10.24114/pjkr.v2i1.7843.

[8] I. Jeffreys, "Movement training for field sports: Soccer," Strength Cond. J., vol. 30, no. 4, 2008, DOI: 10.1519/SSC.0b013e31818021c1.

[9] K. E. Cohen, P. J. Morgan, R. C. Plotnikoff, R. Callister, and D. R. Lubans, "Fundamental movement skills and physical activity among children living in low-income communities: a cross-sectional study," Int. J. Behav. Nutr. Phys. Act., vol. 11, no. 1, p. 49, 2014, DOI: 10.1186/14795868-11-49.

[10] S. Byun, C. An, M. Kim, and D. Han, "The effects of an exercise program consisting of basic taekwondo movements on posture correction," $J$. Phys. Ther. Sci., vol. 26, no. 10, 2014, DOI: 10.1589/jpts.26.1585.

[11] A. M. Apriliani, Y. Yasbiati, and E. Elan, "Meningkatkan Keterampilan Gerak Lokomotor Anak Usia 5-6 Tahun Di Kelas B Hijau Melalui
Permainan Engklek Rintangan Di Tk Negeri Pembina Kota Tasikmalaya," J. Paud Agapedia, vol. 3, no. 2, pp. 178-190, 2020, doi: 10.17509/jpa.v3i2.26680.

[12] K. L. Staples and G. Reid, "Fundamental Movement Skills and Autism Spectrum Disorders," J. Autism Dev. Disord. 2009 402, vol. 40, no. 2, pp. 209-217, Aug. 2009, DOI: 10.1007/S10803-0090854-9.

[13] J. Beaty, Observing the development of the young child, 3rd ed. New York: Mac Millan Publishing Company, 1994.

[14] A. Palmizal, D. Pujianto, Nurkadri, and A. A. N. P. Laksana, "Development of a creative gymnastics model to improve basic locomotor movements for students in elementary school," Int. J. Hum. Move. Sport. Sci., vol. 8, no. 6, 2020, DOI: 10.13189/saj.2020.080714.

[15] M. Marinšek and O. Denac, "The Effects of an Integrated Programme on Developing Fundamental Movement Skills and Rhythmic Abilities in Early Childhood," Early Child. Educ. J. 2020 486, vol. 48, no. 6, pp. 751-758, Feb. 2020, DOI: 10.1007/S10643-020-01042-8.

[16] A. Hidayat, "Peningkatan Aktivitas Gerak Lokomotor, Nonlokomotor Dan Manipulatif Menggunakan Model Permainan Pada Siswa Sekolah Dasar," J. Pendidik. Jasm. Dan Olahraga, vol. 2, no. 2, p. 21, 2017, doi: 10.17509/jpjo.v2i2.8175.

[17] J. Hendra and G. I. Putra, "Mengembangkan Keterampilan Gerak Dasar Manipulatif Bagi Anak Melalui Permainan Olahraga di Taman KanakKanak," J. Muara Pendidik., vol. 4, no. 2, 2019, doi: 10.52060/mp.v4i2.181.

[18] N. M. Siregar, E. F. N. Sari, M. Budiningsih, and Zulham, "The basic learning model of traditional motion-based games for early childhood (5-6) years," Int. J. Hum. Move. Sport. Sci., vol. 9, no. 1, 2021, DOI: 10.13189/saj.2021.090111.

[19] S. Morioka, T. Fukumoto, M. Hiyamizu, A. Matsuo, H. Takebayashi, and K. Miyamoto, "Changes in the equilibrium of standing on one leg at various life stages," Curr. Gerontol. Great. Res., vol. 2012, 2012, DOI: 10.1155/2012/516283.

[20] S. Fukashiro, P. V. Komi, M. Järvinen, and M. Miyashita, "In vivo Achilles tendon loading' during jumping in humans," Eur. J. Appl. Physiol. Occup. Physiol., vol. 71, no. 5, 1995, DOI: 10.1007/BF00635880.

[21] M. Beerse and J. Wu, "Vertical stiffness and 
balance control of two-legged hopping in-place in children with and without Down syndrome," Gait Posture, vol. 63, 2018, DOI: 10.1016/j.gaitpost.2018.04.026.

[22] T. Akay, H. J. Acharya, K. Fouad, and K. G. Pearson, "Behavioral and electromyographic characterization of mice lacking EphA4 receptors," J. Neurophysiol., vol. 96, no. 2, 2006, DOI: 10.1152/jn.00174.2006.

[23] N. Hamilton, W. Weimar, and K. Luttgens, Kinesiology Scientific Basis of Human Motion, 11th ed. Singapore: McGraw-Hill, 2008.

[24] M. Russell, D. Benton, and M. Kingsley, "Reliability and construct validity of soccer skills tests that measure passing, shooting, and dribbling," J. Sports Sci., vol. 28, no. 13, 2010, DOI: 10.1080/02640414.2010.511247.

[25] B. Mackenzie, "Movement Analysis," 2007.

[26] J. P. Zlotnicki, J.-H. Naendrup, G. A. Ferrer, and R. E. Debski, "Basic biomechanics principles of knee instability," Curr. Rev. Musculoskelet. Med. 2016 92, vol. 9, no. 2, pp. 114-122, Mar. 2016, DOI: $10.1007 / \mathrm{S} 12178-016-9329-8$.

[27] H. N. Muhammad, M. A. Al Ardha, A. Priambodo, and S. Wibowo, "Woodball Shooting Technique Analysis in Biomechanic Perspective," Adv. Soc. Sci. Educ. Humanist. Res., vol. 362, no. 1, pp. 6972, Nov. 2019.

[28] D. C. Kartika, A. R. S. Tuasikal, M. A. Al Ardha, and C. B. Yang, "Biomechanical Analysis of Ball Trajectory Direction in Free Throw," Adv. Soc. Sci. Educ. Humanist. Res., vol. 335, pp. 449-453, Aug. 2019.

[29] M. A. Al Ardha et al., "Analisis Biomekanika pada Stroke Nomor 100 Meter Gaya Dada terhadap Swimming Velocity," Media Ilmu Keolahragaan Indones., vol. 9, no. 2, pp. 38-44, Dec. 2019, doi: 10.15294/miki.v9i2.21772.

[30] A. Johnstone, A. R. Hughes, A. Martin, and J. J. Reilly, "Utilising active play interventions to promote physical activity and improve fundamental movement skills in children: a systematic review and meta-analysis," BMC Public Heal. 2018 181, vol. 18, no. 1, pp. 1-12, Jun. 2018, DOI: 10.1186/S12889-018-5687-Z.

[31] D. F. Stodden et al., “A Developmental Perspective on the Role of Motor Skill Competence in Physical Activity: An Emergent Relationship," https://doi.org/10.1080/00336297.2008.10483582, vol. 60, no. 2, pp. 290-306, May 2012, DOI: $10.1080 / 00336297.2008 .10483582$.
[32] D. R. Lubans, P. J. Morgan, D. P. Cliff, L. M. Barnett, and A. D. Okely, "Fundamental Movement Skills in Children and Adolescents," Sport. Med. 2010 4012, vol. 40, no. 12, pp. 1019-1035, Sep. 2012, DOI: $10.2165 / 11536850-000000000-00000$.

[33] M. A. Al Ardha, C.-B. Yang, K. R. Adhe, K. P. Putra, F. D. Khory, and S. Hartono, "Physical Education Curriculum for Early Childhood: Developing Students' Manipulative Skills in Soccer," Adv. Soc. Sci. Educ. Humanity. Res., vol. 173, pp. 226-229, Feb. 2018, DOI: 10.2991/ice17.2018.59.

[34] K. P. J. O. M. D. K. M. W. B. R. P. HG Williams, "Motor skill performance and physical activity in preschool children," Obesity, vol. 16, no. 6, pp. 1421-1426, Jun. 2008, DOI: 10.1038/oby.2008.214.

[35] T. J. Wade, J. Bowden, and H. Jane Sites, "Child Maltreatment and Motor Coordination Deficits among Preschool Children," J. Child Adolesc. Trauma 2017 112, vol. 11, no. 2, pp. 159-162, Aug. 2017, DOI: $10.1007 /$ S40653-017-0186-4

[36] B. Joschtel, S. R. Gomersall, S. Tweedy, H. Petsky, A. B. Chang, and S. G. Trost, "Fundamental movement skill proficiency and objectively measured physical activity in children with bronchiectasis: a cross-sectional study," BMC Pulm. Med. 2021 211, vol. 21, no. 1, pp. 1-7, Aug. 2021, DOI: 10.1186/S12890-021-01637-W.

[37] G. D. Lestari, K. R. Adhe, and M. A. Al Ardha, "Children Motor Development with Authoritarian Parenting During the Industrial Revolution Era 4.0," Adv. Soc. Sci. Educ. Humanity. Res., vol. 382, pp. 87-89, Dec. 2019, DOI: 10.2991/icet19.2019.21 